\title{
Pengaruh Kepemimpinan Transformasional Terhadap Kepuasan Kerja Pada PT. RAPP di Departemen Water Management Estate Pulau Padang Kabupaten Meranti
}

\author{
NURHAYANA \\ Sekolah Tinggi Ilmu Ekonomi Riau (STIER) \\ Jln. HR. Subrantas 57 Panam Pekanbaru 28293 Telp. (0761) 63237 \\ E-mail : nurhayana18@gmail.com
}

\begin{abstract}
The purpose of this study was to find out the Influence of Transformational Leadership on Employee's Satisfaction at the Water Management Estate Department PT.RAPP IN Pulau Padang, Meranti. The research method used is descriptive quantitative method, and data analysis technique used is simple linear regression analysis. There are 41 respondents in this research which are employees at the Water Management Estate Department PT.RAPP in Padang Island of Meranti Regency, which amounted to.Hypothesis testing used simple regression analysis. Descriptive analysis showed the good result or score in both variables between transformational leadership and job satisfaction. Results of regression analyzes with SPSS. From the analysis obtained in this study shows that the variable compensation significant effect on job satisfaction.
\end{abstract}

Keywords: Transformational Leadership, Job Satisfaction

Sumber daya manusia yaitu karyawan didalam suatu perusahaan memegang peranan yang sangat penting yaitu sebagai roda perusahaan, tanpa adanya sumber daya manusia sudah barang tentu perusahaan tidak akan dapat menjalankan operasinya. Potensi setiap sumber daya manusia inilah yang harus dapat dimanfaatkan dengan sebaik-baiknya sehingga mampu memberikan output yang optimal. Perusahaan harus mampu menciptakan kondisi yang dapat mendorong untuk mengembangkan dan meningkatkan kemampuannya dengan optimal. Untuk mencapainya perusahaan memiliki upaya yang dapat ditempuh salah satunya dengan memberikan teladan yang baik dan memuaskan. Kepuasan kerja merupakan masalah strategis, karena tidak terpenuhinya kepuasan kerja akan berdampak kepuasan kerja karyawan.

Salah satu perusahaan yang memperhatikan faktor kepemimpinan, dan kepuasan kerja adalah PT. RAPP Estate Pulau Padang, Kepemimpinan saat ini paham terhadap situasi lingkungan kerja, tidak mempersulit karyawan menunjang peningkatan kinerja seperti peralatan keselamatan kerja dan fasilitas kerja lainnya,sistem kepercayaan tinggi terhadap bawahan, akan tetapi apabila karyawan melakukan satu kesalahan saja maka pimpinan tidak akan percaya lagi meskipun karyawan tersebut memiliki kinerja yang baik,pimpinan juga kurang profesional. Menurunnya kepuasan kerja karyawan bisa dianalisis dari sisi pemimpin yaitu pimpinan kurang peka dengan apa yang diinginkan oleh bawahan, sebagai contoh sebagian karyawan yang belum pernah mengalami rotasi maupun mutasi untuk jangka waktu yang relatif panjang dalam pekerjaannya, sehingga menimbulkan kejenuhan bagi karyawan yang berdampak pada kepuasan kerja. Seperti diketahui kepemimpinan yang cocok bagi bawahan akan sangat berpengaruh terhadap kerja mereka yaitu dengan adanya kepuasan kerja bagi mereka, sehingga karyawan dalam melaksanakan pekerjaannya akan merasa lebih aman, terlindungi, dan puas.

Data turn over atau data keluar masuknya karyawan pada PT RAPP departemen water management estate Pulau Padang dalam lima tahun terakhir, dapat 
ditarik kesimpulan yaitu data keluar masuknya karyawan dalam lima tahun terakhir cukup stabil.

Selain dari pada itu untuk melihat kepuasan kerja karyawan dapat pula dilihat dari absensi karyawan, karena jika karyawan merasa puas atas pekerjaannya tentu tingkat ketidakhadirannya rendah.

Persentase ketidakhadiran kese luruhan karyawan PT RAPP departemen water management estate pulau Padang. Maka dapat disimpulkan persentase ketidakhadiran karyawan tiap tahunnya mengalami penurunan.

Sistem penilaian kinerja tidak hanya berguna untuk mengevaluasi kerja karyawan, tetapi juga untuk mengetahui tingkat kepuasan kerja karyawan yang menyebabkan terjadinya peningkatan atau penurunan kinerja karyawan, sehingga akan memberikan feed back yang tepat untuk keberlangsungan perusahaan.

Menurut Rivai dan Mulyadi (2012: 133), kepemimpinan pada dasarnya melibatkan orang lain, melibatkan distribusi kekuasaan yang tidak merata antara pemimpin dan anggota kelompok, menggerakkan kemampuan dengan menggunakan berbagai bentuk kekuasaan untuk mempengaruhi tingkah laku bawahan, dan menyangkut nilai. Empat sifat umum yang mempunyai pengaruh terhadap keberhasilan kepemimpinan organisasi, yaitu: 1. Kecerdasan; 2. Kedewasaan; 3. Motivasi diri dan dorongan berprestasi; 4 . Sikap hubungan kemanusiaan.

Menurut Robbins (2008: 120) kepemimpinan transformasional pada hakikatnya menekankan seorang pemimpin perlu memotivasi para bawahannya untuk melakukan tanggung jawab mereka lebih dari yang mereka harapkan. Pemimpin transformasional harus mampu mendefinisikan, mengkomunikasikan dan mengartikulasikan visi organisasi, dan bawahan harus menerima dan mengakui kredibilitas pemimpinnya. Dengan demikian, pemimpin transformasional merupakan pemimpin yang karismatik dan mempunyai peran sentral dan strategis dalam membawa organisasi mencapai tujuannya. Hughes et al. (2012: 542) mengemukakan bahwa pemimpin transformasional memiliki visi, keahlian retorika, dan pengelolaan kesan yang baik dan menggunakannya untuk mengembangkan ikatan emosional yang kuat dengan pengikutnya. Pemimpin transformasional diyakini lebih berhasil dalam mendorong perubahan organisasi karena tergugahnya emosi pengikut serta kesediaan mereka untuk bekerja mewujudkan visi sang pemimpin. Menurut Robbins dan Judge (2008: 90) pemimpin transformasional adalah pemimpin yang menginspirasi para pengikutnya untuk mengenyampingkan kepentingan pribadi mereka demi kebaikan organisasi dan mereka mampu memiliki pengaruh yang luar biasa pada diri para pengikutnya, Mereka menaruh perhatian terhadap kebutuhan pengembangan diri para pengikutnya, mengubah kesadaran para pengikut atas isu-isu yang ada dengan cara membantu orang lain memandang masalah lama dengan cara yang baru, serta mampu menyenangkan hati dan menginspirasi para pengikutnya untuk bekerja keras guna mencapai tujuan-tujuan bersama.

$$
\text { Yukl }
$$

(2010:

316-319)

mengemukakan beberapa pedoman bagi para pemimpin yang berusaha untuk menginspirasikan dan memotivasi pengikut, yaitu:

Menyatakan visi yang jelas dan menarik

Para pemimpin transformasional memperkuat visi yang ada atau membangun komitmen terhadap sebuah visi baru. Sebuah visi yang jelas mengenai apa yang dapat dicapai organisasi atau akan jadi apakah sebuah organisasi itu akan membantu orang untuk memahami tujuan, sasaran dan prioritas dari organisasi.

Menjelaskan bagaimana visi tersebut dapat dicapai

Tidaklah cukup hanya menyampaikan sebuah visi yang menarik, pemimpin juga harus meyakinkan para pengikut bahwa visi itu memungkinkan. Amatlah penting untuk membuat hubungan yang jelas antara visi itu dengan sebuah

$$
\text { p.ISSN: 2407-800X e.ISSN: 2541-4356 }
$$


strategi yang dapat dipercaya untuk mencapainya. Hubungan ini lebih mudah dibangun jika strateginya memiliki beberapa tema jelas yang relevan dengan nilai bersama dari para anggota organisasi.

Bertindak secara rahasia dan optimis

Para pengikut tidak akan meyakini sebuah visi kecuali jika pemimpinnya memperlihatkan keyakinan diri dan pendirian. Pemimpin harus tetap optimis tentang kemungkinan keberhasilan organisasi dalam mencapai visinya, khususnya dalam menghadapi halangan dan kemunduran sementara. Keyakinan dan optimisme seorang pemimpin dapat amat menular. Keyakinan diperlihatkan baik dalam perkataan maupun tindakan.

Memperlihatkan keyakinan terhadap pengikut

Pengikut akan memiliki kinerja yang lebih baik saat pemimpinnya memiliki harapan yang tinggi bagi mereka dan memperlihatkan keyakinan terhadap mereka. Menggunakan tindakan dramatis dan simbolis untuk menekankan nilai-nilai penting

Tindakan dramatis dengan perilaku kepemimpinan yang konsisten dengan visi organisasi merupakan cara efektif untuk menekankan nilai penting. Tindakan simbolis untuk mencapai sebuah sasaran penting atau mempertahankan sebuah nilai penting akan memberikan pengaruh saat pemimpin itu membuat resiko kerugian pribadi yang cukup besar, membuat pengorbanan diri, atau melakukan hal-hal yang tidak konvensional.

Memimpin dengan memberikan contoh

Salah satu cara seorang pemimpin mempengaruhi komitmen bawahan adalah dengan menetapkan sebuah contoh dari perilaku yang dapat dijadikan contoh dalam interaksi keseharian dengan bawahan. Seorang pemimpin yang meminta bawahan untuk membuat pengorbanan khusus harus menetapkan sebuah contoh dengan melakukan hal yang sama. Nilai-nilai yang menyertai seorang pemimpin harus diperlihatkan dalam perilakunya sehari-hari, dan harus dilakukan secara konsisten bukan hanya saat diperlukan.
Memberikan kewenangan kepada orangorang untuk mencapai visi itu

Pemimpin mendelegasikan kewenangan kepada bawahan untuk keputusan tentang bagaimana melakukan pekerjaan. Ini berarti pemimpin meminta bawahan untuk menentukan sendiri cara terbaik untuk menerapkan strategi atau mencapai sasaran.

Menurut Pramastuti dalam Danang Sunyoto dan Burhanudin (2015:107) mengemukakan adanya lima karakteristik kepemimpinan transformasional, yaitu: Karisma Kepemimpinan; Inspirasional Kepemimpinan; Kepercayaan; Rangsangan Intelektual; Perhatian Individu.

Salah satu sasaran manajemen sumber daya manusia dalam suatu perusahaan adalah terciptanya kepuasan kerja anggota organisasinya. Kepuasan kerja karyawan yang tinggi cenderung akan meningkatkan produktivitas kerja karyawan yang juga akan berdampak positif pada pencapaian tujuan perusahaan. Beberapa ahli mengemukakan definisi mengenai kepuasan kerja, diantaranya yaitu : Kepuasan kerja menurut Marihot (2007:290) adalah :

"Sejauh mana individu merasakan secara positif/negatif berbagai macam faktor/dimensi dari tugas-tugas dalam pekerjaannya".

Sedangkan menurut Veithzal Rivai (2011:856) mengatakan "Kepuasan kerja adalah evaluasi yang menggambarkan seseorang atas perasaan sikapnya senang atau tidak senang, puas atau tidak puas dalam bekerja". Sedangkan Sondang P Siagian (2011:295) berpendapat bahwa "Kepuasa kerja adalah suatu cara pandang seseorang baik yang bersifat positif maupun yang bersifat negatif tentang pekerjaannya".

Setiap individu memiliki tingkat kepuasan yang berbeda-beda, hal ini disebabkan karena adanya perbedaaan tingkat kepuasan dan kebutuhan dari masing-masing pihak.Menurut Veithzal Rivai (2011:856) mengemukakan teori kepuasan kerja sebagi berikut: 
Discrepancy Theory (Teori ketidaksesuaian)

Teori ini mengukur kepuasan kerja seseorang dengan menghitung selisih antara sesuatu yang seharusnya dengan kenyataan yang dirasakan. Sehingga apabila kepuasannya diperoleh melebihi dari yang diinginkan, maka orang akan menjadi lebih puas lagi, sehingga terdapat discrepancy, tetapi merupakan discrepancy yang positif. Kepuasan kerja seseorang tergantung pada selisih antara sesuatu yang dianggap akan didapatkan dengan apa yang dicapai.

Equity Theory (Teori Keadilan)

Teori ini mengemukakan bahwa orang akan merasa puas atau tidak puas, tergantung pada ada atau tidaknya keadilan (equity) dalam suatu situasi, khususnya situasi kerja. Menurut teori ini komponen utama dalam teori keadilan adalah input, hasil, keadilan dan ketidakadilan.

Two Faktor Theory (Teori Dua Faktor)

Menurut teori ini kepuasan kerja dan ketidakpuasan kerja itu merupakan hal yang berbeda. Kepuasan dan ketidakpuasan terhadap pekerjaan itu bukan suatu variabel yang kontinu. Teori ini merumuskan karakteristik pekerjaan menjadi dua kelompok yaitu satifies atau motivator dan dissatisfies.

Satisfies ialah faktor-faktor atau situasi yang dibutuhkan sebagai sumber kepuasan kerja yang terdiri dari : pekerjaan yang menarik, penuh tantangan, ada kesempatan untuk berprestasi, kesempatan memperoleh penghargaan dan promosi. Terpenuhnya faktor tersebut akan menimbulkan kepuasan, namun tidak terpenuhinya faktor ini tidak selalu mengakibatkan ketidakpuasan.

Dissatisfies (hygiene faktor) adalah faktor-faktor yang menjadi sumber ketidakpuasan, yang terdiri dari : gaji/upah, pengawasan, hubungan antara pribadi, kondisi kerja dan setatus. Faktor ini diperlukan untuk memenuhi dorongan biologis serta kebutuhan dasar karyawan. Jika tidak terpenuhi faktor ini, karyawan tidak akan puas. Namun, Jika besarnya faktor ini memadai untuk memenuhi kebutuhan tersebut, karyawan tidak akan kecewa meskipun belum terpuaskan.

Dengan adanya penjelasan diatas, maka dapat dilihat adanya dua kelompok faktor yang terpisah. Satu kelompok yang dapat menyebabkan kepuasan kerja, sedangkan kelompok faktor yang lain dapat pula meningkatkan kepuasan kerja. Tetapi apabila tidak dapat terpenuhi maka akan menurunkan kepuasan kerja dan tidak akan menimbulkan rasa ketidakpuasan yang berlebihan.

Faktor - faktor yang mempengaruhi kepuasan kerja menurut Anwar Prabu (2006:478) ada dua faktor yang mempengaruhi kepuasan kerja, yaitu:Faktor pegawai, yaitu kecerdasan (IQ), kecakapan Khusus, umur, jenis kelamin, kondisi fisik, pendidikan,pengalaman kerja, masa kerja, kepribadian, emosi, cara berfikir, persepsi dan sikap kerja. 2. Faktor pekerjaan, yaitu jenis pekerjaan, stuktur organisasi, pangkat (golongan), kedudukan, mutu pengawasan, jaminan, financial, kesempatan promosi jabatan, interaksi sosial, dan hubungan kerja.

Kepuasan kerja seseorang dipengaruhi oleh banyak faktor, tidak hanya gaji, tetapi terkait dengan pekerjaan itu sendiri, dengan faktor lain seperti hubungan dengan atasan,rekan sekerja, lingkungan kerja, dan aturan-aturan. Berdasarkan para ahli mengklasifikasikan faktor-faktor yang mempengaruhi kepuasan kerja yang berkaitan dengan beberapa aspek menurut Marihot (2007:291), yaitu : 1. Gaji, yaitu jumlah bayaran yang diterima sesorang sebagai akibat dari pelaksanaan kerja apakah sesuai dengan kebutuhan dan dirasakan adil. 2. Pekerjaan itu sendiri, yaitu isi pekerjaan yang dilakukan seseorang apakah memiliki elemen yang memuaskan. 3. Rekan sekerja, yaitu temanteman kepada siapa seseorang senantiasa berinteraksi dalam pelaksanaan pekerjaan. Seseorang dapat merasakan rekan kerjanya sangat menyenangkan atau tidak menyenangkan. 4. Atasan, yaitu sesorang yang senantiasa memberi perintah atau petunjuk dalam pelaksanaan kerja. Cara- 
cara atasan dapat tidak menyenangkan bagi sesorang atau menyenangkan dan hal ini dapat mempengaruhi kepuasan kerja. 5. Promosi, yaitu kemungkinan seseorang dapat berkembang melalui kenaikan jabatan. Seseorang dapat merasakan adanya kemungkinan yang besar untuk naik jabatan atau tidak, proses kenaikan jabatan kurang terbuka atau terbuka. Ini juga dapat mempengaruhi tingkat kepuasan kerja seseorang. 6. Lingkungan kerja yaitu lingkungan fisik dan psikologis.

Indikator kepuasan kerja menurut Veithzal Rivai (2009: 260), indikator atau faktor-faktor yang dapat mengukur kepuasan kerja seorang karyawan adalah : Isi pekerjaan, penampilan tugas pekerjaan yang aktual dan kontrol terhadap pekerjaan; Supervisi; Organisasi dan manajemen; Kesempatan untuk maju; Gaji dan keuntungan dalam bidang financial; Rekan kerja; Kondisi pekerjaan

Robbins dan Judge (2008: 90) mengemukakan bahwa pemimpin transformasional adalah pemimpin yang menginspirasi para pengikutnya untuk mengenyampingkan kepentingan pribadi mereka demi kebaikan organisasi dan mereka mampu memiliki pengaruh yang luar biasa pada diri para pengikutnya. Situasi organisasi dengan kepemimpinan transformasional membuat karyawan selalu bergairah dalam bekerja. Selalu ada sesuatu yang baru dan membuat karyawan akan mendapatkan prestasi yang menggembirakan. Kepemimpinan transformasional ini sangat kuat pengaruhnya terhadap munculnya kepuasan kerja karyawan terutama karena karakteristik pemimpin yang peduli pada keberbedaan kemampuan karyawan. Hal ini dibuktikan dengan adanya penelitian yang dilakukan oleh Dewi Lingga Sugiarti (2007) dan Basilius Redan Werang (2014) yang menyatakan bahwa kepemimpinan transformasional berpengaruh signifikansi terhadap kepuasan. Berdasarkan uraian yang telah dijelaskan di atas, maka peneliti mengajukan hipotesis sebagai berikut:

\section{METODE}

Lokasi penelitian ini adalah di PT. Riau Andalan Pulp and Paper (RAPP) estate Pulau Padang Kabupaten Meranti di departemen water management.

PT. Riau Andalan Pulp and Paper (RAPP) merupakan sebuah perusahaan atau industri yang bergerak dalam bidang produk pulp (bubur kertas) dan paper (kertas) yang merupakan suatu perusahaan pulp terbesar di Asia Pasifik.

Jenis data yang digunakan dalam penelitian ini pada dasarnya ada 2 data. Adapun jenis dan sumber data yang dikumpulkan dalam penelitian ini adalah : Data Primer. Data primer adalah sumber data yang langsung diberikan data kepada pengumpul data. Yaitu data karyawan PT RAPP departemen water management estate Pulau Padang Kabupaten Meranti. b. Data Sekunder. Data sekunder adalah sumber yang secara tidak langsung memberikan data kepada pengumpul data. Data sekunder dalam penelitian ini berasal dari buku, jurnal, artikel dari internet, dan berbagai sumber lainnya yang berkaitan dengan kompensasi dan kepuasan kerja karyawan.

Populasi adalah keseluruhan subjek penelitian. Populasi dalam penelitian ini meliputi seluruh tenaga kerja pada PT. RAPP sektor Pelalawan di departemen water management tahun 2016 yang berjumlah 41 orang karyawan.

Sampel

Sugiono (2013:85), menyatakan bahwa sampling jenuh adalah teknik penentuan sampel bila semua anggota populasi digunakan sebagai sampel. Sampel yang digunakan untuk penelitian ini adalah sebanyak 41 orang.

Dalam penelitian ini penulis menggunakan teknik pengumpulan data melalui : Observasi, yaitu digunakan untuk mendapatkan keterangan atau informasi yang berguna untuk melengkapi bahan yang dianggap perlu dalam penelitian ini. Kuesioner. Yaitu merupakan pengumpulan data melalui angket atau daftar pertanyaan yang diajukan kepada responden terpilih. 
Pertanyaan dalam kuesioner dibuat berdasarkan skala likert dengan alternatif jawaban, yaitu: sangat setuju, setuju,kurang setuju, tidak setuju dan sangat tidak setuju. Selanjutnya data kualitatif yang sudah diangkakan tersebut diolah sesuai dengan teknik analisis data.

Teknik analisis yang akan digunakan penulis adalah dengan menggunakan : Metode Deskriptif, yaitu penganalisaan data yang bersifat penjelasan atau penguraian dari data atau informasi yang dikaitkan dengan teori yang mendukung pembahasan. Metode Kuantitatif, yaitu metode yang menunjukkan kepada riset dalam bentuk rumus-rumus. Untuk mengetahui seberapa besar Pengaruh Kompensasi Terhadap Kepuasan Kerja Karyawan Pada PT RAPP Di Departemen Water Management Estate Pulau Padang Kabupaten Meranti, maka penulis menggunakan analisa regresi linier yang hanya melibatkan dua variabel (X) dan (Y) (Iqbaal Hasan 2009:250).

\section{HASIL}

Analisis ini digunakan untuk mengetahui pengaruh variabel bebas Disipli kerja terhadap variabel terikat Kepuasan kerja. Adapun persamaan rumus regresi linear sederhana adalah sebagai berikut:

$\mathrm{Y}=\mathrm{a}+\mathrm{bX}$

$\mathrm{Y}=$ Variabel Terikat (Kepuasan kerja)

$\mathrm{a}=$ Konstanta

$\mathrm{b}=$ Koefisien arah dari regresi, yang menunjukkan angka peningkatan atau penurunan variabel dependen atau mengukur besar pengaruh $\mathrm{X}$ terhadap $\mathrm{Y}$, jika $\mathrm{X}$ naik satu unit.

$\mathrm{X}=$ Variabel bebas (Kepemimpinan Transformasional)

Dari tabel hasil output SPSS dapat diperoleh persamaan regresi linier sederhana sebagai berikut:

$\mathrm{Y}=11,458+0,020 \mathrm{X}$

Persamaan ini dapat diartikan sebagai berikut:

a. Konstanta sebesar 11,458 artinya jika variabel bebas $\mathrm{X}$ (Kepemimpinan Transformasional) tetap, maka variabel terikat $\mathrm{Y}$ (Kepuasan Kerja) sebesar 11,458

b. Koefisien regresi variabel $\mathrm{X}$ $(0,020)$ sebesar 0,020 berarti jika variabel Kepemimpinan Transformasional mengalami kenaikan 1 satuan, maka Kepuasan Kerja Karyawan juga akan mengalami kenaikan sebesar 0,020 satuan. Koefisien bernilai positif artinya terjadi hubungan positif antara Kepemimpinan

Transformasional dengan Kepuasan Kerja Karyawan. Semakin besar Kepemimpinan Transformasioanl maka Kepuasan Kerja Karyawan akan semakin baik.

\section{Uji-t}

Uji t digunakan untuk mengetahui tingkat signifikan pengaruh variabel bebas terhadap variabel terikat. Dari hasil regresi output dapat dilihat $\mathbf{t}$-tabel $=\mathbf{1 , 6 8 5}$ dari hasil output SPSS.

$\mathrm{t}_{\text {-hitung }}=2.150>1.685$ maka terdapat pengaruh Variabel $\mathrm{X}$ (Kompensasi) terhadap variabel $\mathrm{Y}$ (Kepuasan Kerja Karyawan).

\section{Analisis Koefisien Determinasi $\left(\mathbf{R}^{\mathbf{2}}\right)$}

Nilai koefisien determinasi atau $\mathrm{R}$ Square $\left(\mathrm{R}^{2}\right)$ digunakan untuk mengetahui seberapa besar persentase pengaruh variabel bebas (Kepemimpinan Transformasional) terhadap variabel terikat (Kepuasan kerja). Dari hasil pengolahan dengan program SPSS diperoleh hasil sebagai berikut: Nilai koefisien R Square $\left(\mathrm{R}^{2}\right)$ sebesar 0.177 $(17.7 \%)$ ini menerangkan Kepemimpinan Transformasional pada PT. RAPP Estate Pulau Padang kabupaten Meranti berpengaruh terhadap Kepuasan Kerja Karyawan sebesar $17.7 \%$. Sedangkan sisanya sebesar $82.3 \%(100 \%$ - $17.7 \%)$ menggambarkan variabel bebas lainnya yang tidak diamati dalam penelitian ini. 


\section{PEMBAHASAN}

Hasil penelitian menunjukkan bahwa kepemimpinan transformasional berpengaruh positif dan signifikan terhadap kepuasan kerja karyawan. Kontribusi kepemimpinan transformasional berpengaruh positif terhadap kepuasan kerja ,maka dapat disimpulkan bahwa kepemimpinan transformasional berpengaruh positif terhadap kepuasan kerja, sehingga dapat dinyatakan bahwa hipotesis diterima.

Kepemimpinan merupakan salah satu faktor yang sangat penting bagi keberhasilan manajemen organisasi. Kepemimpinan yang efektif akan mampu mendorong motivasi organisasi sehingga produktifitas, loyalitas dan kepuasan bawahan atau anggota organisasi meningkat. Pada awalnya banyak yang berpendapat bahwa pemimpin itu dilahirkan, namun dengan berkembangnya pengetahuan diketahui bahwa terbentuknya kepemimpinan yang efektif dapat dipelajari. Pimpinan dalam menjalankan tugasnya belum menunjukkan hubungan yang akrab dengan bawahan misalnya bersikap ramah, membantu dan membela kepentingan bawahan, bersedia menerima konsultasi bawahan dan memberikan kesejahteraan. Hal ini ditunjukkan dari sikap pimpinan yang kurang terbuka dengan karyawan, pimpinan tidak melibatkan karyawan dalam proses pengambilan keputusan.

Selain itu, berdasarkan hasil analisis kategorisasi, mayoritas karyawan menilai kepemimpinan transformasional dalam kategori sedang Hasil kategorisasi tersebut mendukung fenomena yang terjadi di lapangan, dimana kepemimpinan transformasional yang dijalankan pemimpin belum maksimal karena pimpinan kurang peka dengan apa yang diinginkan oleh bawahan Kepemimpinan melibatkan hubungan pengaruh yang mendalam, yang terjadi diantara orang-orang yang menginginkan perubahan yang signifikan, dan perubahan tersebut mencerminkan tujuan yang dimiliki bersama oleh pemimpin dan pengikutnya (bawahan). Kepemimpinan yang efektif hanya akan terwujud apabila dijalankan sesuai dengan fungsinya. Fungsi kepemimpinan itu berhubungan langsung dengan situasi sosial dalam kehidupan kelompok/organisasi masing-masing, yang mengisyaratkan bahwa setiap pemimpin berada didalam dan bukan diluar situasi. Kepemimpinan transformasional dalam organisasi merupakan penggambaran langkah kerja bagi karyawan yang berada dibawahnya. Karyawan yang sudah memiliki kepuasan kerja merasa bahwa pemimpin dalam melakukan tugas kepemimpinannya selalu dapat memperhatikan aspirasi dan juga dapat mengatur tugas-tugas yang harus diperhatikan dengan baik, akan dapat menimbulkan suatu perasaan senang pada karyawan terhadap pemimpin tersebut.

Oleh karena itu, kepemimpinan transformasional merupakan hal yang penting dalam meningkatkan kepuasan yang ada pada karyawan. Hasil penelitian ini mendukung penelitian sebelumnya yang dilakukan oleh Hidayat (2011) melakukan penelitian tentang pengaruh kepemimpinan transformasional terhadap kepuasan kerja karyawan yang tergabung dalam koperasi angkutan umum jalur ParangtritisYogyakarta. Hasil penelitian menunjukkan bahwa terdapat pengaruh kepemimpinan transformasional terhadap kepuasan kerja karyawan. Penelitian ini menyatakan bahwa kepemimpinan transformasional berpengaruh signifikan terhadap kepuasan kerja karyawan. Oleh karena itu, perusahaan perlu menerapkan kepemimpinan transformasional yang memada

\section{SIMPULAN}

Berdasarkan uraian di atas, maka dapat disimpulkan bahwa kepemimpinan transformasional berpengaruh positif dan signifikan terhadap kepuasan kerja karyawan. Kontribusi kepemimpinan transformasional berpengaruh positif terhadap kepuasan kerja ,maka dapat disimpulkan bahwa kepemimpinan transformasional berpengaruh positif terhadap kepuasan kerja, sehingga dapat dinyatakan bahwa hipotesis diterima.

$$
\text { p.ISSN: 2407-800X e.ISSN: 2541-4356 }
$$




\section{DAFTAR RUJUKAN}

Danang, Sunyoto dan Burhanudin. (2011). Perilaku Organisasi. Seturan Utara, Sleman, Yogyakarta : Penerbit CAPS.

Ghozali, Imam. 2011. Aplikasi Analisis Multivariate dengan program SPSS, Badan Penerbit Universitas Diponegoro, Semarang.

Hariandja, Marihot T.E. 2007. Manajemen Sumber Daya Manusia. Jakarta. Grasindo

Hughes, Richard L. Et.al. 2012. Leadership : memperkaya pelajaran dari pengalaman. Terjemahan: Putri iva Izzati, Jakarta: Salemba Humanika.

Rivai, Veithzal 2009. Manjemen Sumber Daya Manusia Untuk Perusahaan. Dari Teori Ke Praktek. Rajawali Pers: Jakarta.

.2011, Manajemen Sumber Daya Manusia untuk Perusahaan: dari Teori ke Praktik, Jakarta : RajaGrafindo Persada

Rivai, Veithzal dan Deddy Mulyadi. 2012. Kepemimpinan dan Perilaku Organisasi Edisi Ketiga. Jakarta : PT. Rajagrafindo Persada.

Robbins,Stephen. 2008. Organizational Behavior, Tenth Edition (Perilaku Organisasional Edisi Kesepuluh), Alih Bahasa Drs. Benyamin Molan. Jakarta PT. Macanan Jaya Cemerlang.

Siagian, Sondang P. (2011). Manajemen Sumber Daya Manusia. Jakarta: Bumi Aksara

Sugiyono. 2013. Metodologi Penelitian Manajemen. Bandung: Alfabeta
Sugiyono. 2011. Statistika untuk Penelitian. Bandung: Alfabeta

Mangkunegara, Anwar Prabu. 2008. Manajemen Sumber Daya Manusia Perusahaan. Remaja Rosdakarya, Bandung

Yukl,Gary. 2010. Kepemimpinan Dalam Organisasi, Edisi Kelima. Jakarta: PT.Indeks. 